\title{
ERN1 wt Allele
}

National Cancer Institute

\section{Source}

National Cancer Institute. ERN1 wt Allele. NCI Thesaurus. Code C113613.

Human ERN1 wild-type allele is located in the vicinity of $17 q 24.2$ and is approximately 88 $\mathrm{kb}$ in length. This allele, which encodes serine/threonine-protein kinase/endoribonuclease IRE1, plays a role in the unfolded protein response. 